\title{
Marketing/Sales Students' Understanding Of What Counts As Sales
}

Leon Hoshower, Ohio University, USA

Ashok K. Gupta, Ohio University, USA

\begin{abstract}
Improper sales revenue recognition is the single largest issue contributing to financial restatements. Understanding and applying the rules of sales revenue recognition is not just an accounting problem; it is a marketing problem, too. Thus, it is important that the sales force has a basic understanding of the rules of sales recognition and be aware of when they should seek advice from accounting on the details of sales agreements. Unfortunately, most marketing and sales curricula neither expose nor alert students to sales revenue recognition issues and the resulting ethical, financial, legal and marketing consequences of improper revenue recognition. Such students, after joining the workforce, may pursue certain marketing goals, strategies and tactics which may lead them unknowingly to engage in unethical and/or illegal practices. Our findings based on a survey of 300 undergraduate students highlight the deficiencies in their understanding of what counts as sales. The survey used real cases where SIC found that misreporting of sales has occurred.
\end{abstract}

Keywords: Sales Revenue, Revenue Recognition

\section{INTRODUCTION AND BACKGROUND}

mproper revenue recognition is the single largest issue contributing to financial restatements (Turner C et al. 2001). It has affected firms in the aircraft, communications, energy, food, pharmaceuticals, software, telecommunications, and IT industries, among others. According to the Huron Consulting Group, a Chicago based firm, sales revenue recognition issues were the cause of 85 of the 381 accounting restatements (22\% of cases) of public companies in 2002 (Gillies 2003). From July 1997 to July 2002, the Securities and Exchange Commission (SEC) launched 227 investigations of suspected financial misreporting. 126 of these were related to sales revenue recognition issues (55\% of the cases). Table 1 presents some examples of businesses which have misstated sales data. In some cases the restated sales revenues were almost 80 percent less than the originally stated values.

Table 1: Some Examples of Overstatements of Sales

\begin{tabular}{|l|c|c|c|}
\hline \multicolumn{1}{|c|}{ Company Name } & $\begin{array}{c}\text { 2001 Sales \$mil } \\
\text { Originally Stated }\end{array}$ & $\begin{array}{c}\text { 2001 Sales \$mil } \\
\text { Restated }\end{array}$ & Difference \\
\hline American Electric Power & $\$ 61,257$ & $\$ 12,767$ & $-79 \%$ \\
\hline Coca-Cola & $\$ 20,092$ & $\$ 17,545$ & $-13 \%$ \\
\hline Duke Energy & $\$ 59,503$ & $\$ 18,525$ & $-69 \%$ \\
\hline Dynergy & $\$ 42,242$ & $\$ 9,225$ & $-78 \%$ \\
\hline El Paso & $\$ 57,475$ & $\$ 13,699$ & $-76 \%$ \\
\hline Kellogg & $\$ 8,853$ & $\$ 7,548$ & $-15 \%$ \\
\hline Kimberly-Clark & $\$ 14,524$ & $\$ 13,288$ & $-9 \%$ \\
\hline Oneok & $\$ 6,803$ & $\$ 1,916$ & $-72 \%$ \\
\hline Qwest Communications Intl. & $\$ 19,695$ & $\$ 18,370$ & $-7 \%$ \\
\hline Reliant Resources & $\$ 31,129$ & $\$ 6,491$ & $-79 \%$ \\
\hline
\end{tabular}

Source: Gillies, Andrew T. “Is That Revenue for Real?” Forbes, April 14, 2003, p. 161 
The error in financial statements resulting from improper revenue recognition can mislead some stakeholders about the underlying economic performance of the firm, alter outcomes of certain contractual obligations and agreements, such as bond covenants, trigger managers' bonuses and incentive plans, and alter internal performance evaluations (Healy and Wahlen 1999; Nelson, Elliott, and Tarpley 2003). Properly recognizing sales revenue is especially important when a firm issues new shares of stock or uses stock to fund a business acquisition. Conversely, proper recognition of sales is a prerequisite to properly valuing a potential acquisition. Both the growth pattern of sales and the magnitude of sales affect the perceived health of the company. This, in turn, influences investor and lenders and may impact the firm's ability to attract new customers, suppliers, and distributors, as well as to recruit new employees. This was especially true during the 1990s when investors focused on sales revenues rather than income in determining the market value of internet company stocks. For example, in the late 1990s, Amazon.com could command \$21.6 billion market capitalization without ever having made a profit of one cent. Consequently, web-based companies had powerful incentives to inflate sales (Kahn 2000)

Understanding and applying the rules of revenue recognition is not just an accounting problem; it is a marketing problem, too. It is true that once a contract is signed, the die is cast. At that point, the accounting department will apply the rules of revenue recognition to determine when or if a sale has occurred and will record the transaction. However, prior to the final sales agreement, and perhaps sometimes even after the final sales agreement has been signed, the salesforce may enter into agreements with customers, dealers or business partners that can alter whether or when the firm can recognize revenue. Thus, it is important that the salesforce have a basic understanding of the rules of sales recognition and be aware of when they should seek advice from accounting on the details of sales agreements.

Unfortunately, most marketing and sales curricula neither expose nor alert students to sales revenue recognition issues and the resulting ethical, financial, legal and marketing consequences of improper revenue recognition. Such students, after joining the workforce, may pursue certain marketing goals, strategies and tactics which may lead them unknowingly to engage in unethical and/or illegal practices. Likewise, many sales executives, due to the complexities of the rules surrounding sales revenue recognition, may be inadvertently putting their companies, themselves, and the firm's top executives, in jeopardy, under the Sarbanes-Oxley Act of 2002. This article examines marketing and accounting students' understanding of revenue recognition.

The purposes of this article, are to: (i) highlight if marketing and accounting students can correctly identify if sales have occurred; (ii) report on how confident students are of their answers; and (iii) lastly, to emphasize the need for pedagogical changes.

\section{QUESTIONABLE AND IMPROPER SALES REVENUE RECOGNITION PRACTICES}

A review of literature indicates the following common practices that could lead to improper sales recognition. Butaney, Gupta and Hoshower (2006) describe and illustrate these practices involving B-to-B marketing transactions of real companies, how they violate revenue recognition rules, and probe into potential reasons for pursuing them. Here they are briefly presented:

\section{Channel Stuffing}

Channel stuffing is the practice of shipping an abnormally large quantity of inventory to the company's distributors and recording this mass shipment as sales. This practice is also called "parking of inventory." A company may offer extended payment terms to its distributors for accepting the products early and in large quantities. One issue that arises from "channel stuffing" is whether the distributors have the right to return the unsold goods. If they have that right, then the title to the goods shipped has not passed from the producer to the distributor, and, therefore, a legal sale has not occurred. In this case, the sale occurs only when the distributor sells the product and/or relinquishes the right of return. On the other hand, enticing the distributor to accept unusually large amounts of inventory by offering volume discounts or favorable payment terms does constitute a sale if the distributor accepts the shipment, does not have the right to return the goods, and is legally obligated to pay for them. An exception to this would occur if the supplier had knowledge that the distributor was near bankruptcy and not reasonably expected to be able to make the payments. In this case, the shipment of goods to the distributor 
would still not be a sale until the goods are actually paid for or until the distributor's financial position improves materially.

\section{Right to Return}

Some manufacturers offer liberal product return terms to distributors as a part of their marketing strategy. Such policies encourage distributors to stock new products or products with uncertain demand. The manufacturer would want the distributor to carry a larger stock of inventory to ensure product availability to the customer, prevent stock-out costs (e.g., the customer switching brands), and/or to implement the manufacturer's specific promotion program. Liberal merchandise returns can also be used to signal or communicate the manufacturer's confidence in the product quality, existence of strong market demand, and support for the product, mainly to influence the distributor to carry a larger stock of product inventory. While the product return terms may be used as a part of a competitive strategy, the shipment of goods to a distributor/customer does not constitute a sale if they have the right to return the goods for a refund. This rule of revenue recognition holds whether or not channel stuffing has occurred.

\section{Holding the Books Open}

Holding the books open occurs, for example, when goods that are ordered in December 2008 and shipped in January 2009 are claimed as December 2008's sales. In this situation the sale would properly be claimed in January 2009 and contribute towards 2009's income, rather than 2008's income. Holding the books open represents a clear violation of GAAP (generally accepted accounting principles) and a fraudulent method of overstating sales revenue and income.

\section{Claiming Sales of Services Prior to Performing the Service}

Just as goods usually cannot be claimed as sold until they are shipped, services should not be claimed as sales when a contract is signed, but rather when the services are rendered or provided. Yet, a company that was trying to boost its current sales and profits might be tempted to book an entire contract's revenue up front while spreading out the associated costs over the life of the contract.

\section{Bundling of Goods and Services}

The bundling of goods and services or of various services into a single contract makes the issue of when to recognize sales more complicated and more exposed to potential abuse. For example, suppose a company sells a photocopy machine with a three year service agreement. Proper accounting for this agreement requires that the total amount of the contract be divided into the amount paid for the machine and the amount paid for the service agreement, even if the contract does not specify these amounts. The amount paid for the photocopy machine should be recognized as a sale when the machine is shipped to the customer, but the amount of the service contract will be recognized in increments over the next three years as the service is provided. To further complicate matters, if the seller expects that the third year of the service contract will require more service time and expense than the first two years of the agreement, a larger portion of the revenue from the service contract must be deferred to and recognized in the third year of the agreement than in the first two years.

\section{Barter and Round-Tripping}

In barter transactions, two companies swap the same commodity, with each company recognizing revenue from the exchange, even though little of economic substance has actually transpired. Round trip transactions are similar to barter transactions except that round trip transactions involve an exchange of cash. In a round trip, one company sells a product for cash to another company, which in turn sells an equivalent product back to the initial seller for a similar price, with each company recognizing revenue on its "sale". A company intent on disguising barter transactions or "round tripping" may try to do so by running the transactions through an intermediary, rather than dealing directly with the ultimate counterparty (Kahn 2000). Under current accounting practices only the net amount, that is, the difference between the value given and the value received, can be reported as a sale. 


\section{Recognizing Sales by the Gross Method}

Duke Energy in 2002 reported its sales as $\$ 60$ billion, making it the $13^{\text {th }}$ largest U.S. Corporation. After restating its sales, as required by the SEC, its sales were $\$ 15$ billion. How could such a major discrepancy occur? To balance energy generation and consumption, Duke Energy, like other electric utilities, bought energy from and sold energy to other power companies. Duke reported all of its sales of energy as revenue and all of its purchases of energy as expenses. This accounting procedure is called reporting at gross. Current accounting rules require such transactions of power companies to be reported at net. That is, sales of power to other power companies minus purchases of power from other power companies equals "net" sales. In this situation, the net sale is reported as part of its sales and its purchases of power are not reported as expenses (Gillies 2003).

Reporting sales revenues on a net vs. gross basis was also a revenue recognition issue with Priceline.com. In the third quarter of 1999, Priceline.com reported its sales revenue as $\$ 152$ million. This amount included the full amount customers paid to Priceline for airline tickets, hotel rooms, rental cars, etc. However, much like regular travel agencies, Priceline only keeps a small portion ( $\$ 18$ million that quarter) of the amount remitted by customers, with the bulk going to the airlines, hotels, and car rental companies. If a typical travel agency had these financial results, it would have recognized only the $\$ 18$ million as its revenue. Yet, the SEC has allowed Priceline's reporting. The supporting logic is that unlike travel agencies, which work on commissions, Priceline assumes the risk of ownership as the merchant of record for the items purchased by its customers. Priceline is at risk for any failure of its customers to pay for the tickets (Kahn 2000). However, this risk seems minimal since all customers of Priceline pay with credit cards, on which the credit card company bears the risk of payment default.

In a similar case, that of an online processor of college applications, the SEC ruled differently. The online processor received the college application fees from the potential students, kept a portion of the fees as its commission, and passed the rest on to the respective colleges. The online application processor tried to claim the entire application fee as its revenue. However, the SEC required that the company report only the commissions it received from colleges as its revenue. The SEC asserted that the online processor was not the merchant of record and assumed no risk that a user wouldn't pay. The SEC determined that the application company was an agent of the colleges, whose applications were on the site (Kahn 2000).

\section{Revenue Recognition Could Be Tricky}

Suppose that the marketing division is under pressure to "find extra sales" at the end of a given quarter to meet its performance quotas. With a little creative help, some sales that would normally occur in the following quarter can legitimately be pushed into and counted towards the current quarter. One method of accomplishing this is through channel stuffing. Perhaps purchasers can be persuaded to accept additional merchandise by offering discounts or favorable payment terms. If the purchaser agrees to this arrangement, has no right of return, and if the goods are shipped by the end of the quarter, these "extra" sales can be claimed in the current quarter. If any of the three elements mentioned in the previous sentence are missing, the sale can not be legitimately claimed this quarter. As this example illustrates, revenue recognition issues can be tricky. Thus, the salesforce should consult with accounting to structure contracts so that their end-of-the-quarter sales can be legally recognized in the desired quarter.

In contrast, service contracts signed just before the end of a quarter are of little value in increasing the current quarter's sales. Services are counted as sales only as the service is performed. For a service contract on a photocopy machine, the revenue of the contract would be recognized as the contract runs. Thus, if a service agreement covered the period March 29, 2009 to March 28, 2010, less than 1\% (3 days of the 365 day contract) could be claimed as sales for the quarter ended March 31, 2009.

\section{RESEARCH METHODOLOGY}

Based on the seven improper revenue recognition practices as briefly described earlier and more extensively discussed in Butaney, Gupta and Hoshower (2006), a questionnaire was developed that contained 13 revenue recognition scenarios [Appendix 1]. In each scenario, the respondents were asked whether a sale has 
occurred and the level of their confidence in their answer. This was measured on a 5-point scale, ranging from "very confident" to "very unsure".

Sample: 246 undergraduate students in a Business College who were enrolled in marketing/sales or accounting courses such as: Marketing Research, Professional Selling, Business to Business Marketing, Marketing of Services, Marketing Strategy, Taxation of Business Entities, Intermediate Accounting II, and Accounting Systems classes answered the survey questions. All students had taken marketing principles and two basic accounting courses. In addition, all accounting students had successfully completed Intermediate Accounting I with a "C" or better. The respondents' profile is presented in Table 2.

Table 2: Demographic Profile of Respondents

\begin{tabular}{|c|c|c|c|c|c|}
\hline \multicolumn{6}{|c|}{ Total Sample: 300} \\
\hline \multicolumn{2}{|c|}{ Class Status } & \multicolumn{2}{|c|}{ GPA } & \multicolumn{2}{|c|}{ Gender } \\
\hline Sophomores & $2.7 \%$ & Below 3.0 & $17.2 \%$ & Male & $43 \%$ \\
\hline Juniors & $44.2 \%$ & 3.0 to 3.2 & $29.4 \%$ & Female & $57 \%$ \\
\hline Seniors & $53.1 \%$ & 3.201 to 3.5 & $27.7 \%$ & & \\
\hline \multirow{2}{*}{ Selinots } & & 3.501 to 3.7 & $13.9 \%$ & & \\
\hline & & Above 3.7 & $11.8 \%$ & & \\
\hline \multicolumn{6}{|c|}{ Majors } \\
\hline 126 & \multicolumn{5}{|c|}{ Marketing/Sales major AND Accounting/Finance NOT as second major } \\
\hline 100 & \multicolumn{5}{|c|}{ Accounting/Finance major AND Marketing/Sales NOT as second major } \\
\hline 16 & \multicolumn{5}{|c|}{ Marketing/Sales major AND Accounting/Finance as second major } \\
\hline 52 & \multicolumn{5}{|c|}{ Other Major } \\
\hline
\end{tabular}

\section{RESULTS}

Table 3 presents the survey results for Marketing/Sales majors [who have not declared Finance or Accounting as a second major] and Accounting/Finance majors [who have not declared Marketing or Sales as a second major]. Several interesting observations can be made from Table 3:

$\Rightarrow \quad$ Overall, both marketing/sales (MS) and accounting/finance (AF) majors have serious problems in correctly determining whether a sale has legally occurred. MS students generally have greater difficulty than AF students. Also, MS students were generally less confident in their answers. On average, MS students responded correctly in 6.47 of the 13 revenue recognition cases. This is slightly less than the 6.5 expected score from random selection. The AF students scored 7.7 out of 13 . The difference in average score between the two groups is significant at 0.001 level with $t=4.709$. The AF students not only had a significantly higher success score, but their average confidence level (3.54 out of max of 5) was also significantly greater than that of MS students (3.29 out of $\max$ of 5) with $t=2.676$ and $p<=0.008$. Neither group showed significant differences in scores by gender (male vs. female), class status (junior vs. seniors), or GPA.

Students seem to understand that if a manufacturer shipped more than what the distributor ordered (Situation 2), the excess shipment cannot be considered as sales revenue. However, they have difficulty in understanding how the sales term of "right to return" impacts revenue recognition (Situations 1, 3, 4, and 5). They do not understand that if the distributor has the right to return the unsold goods, then the title to the goods shipped has not passed from the producer to the distributor, and, therefore, a legal sale has not occurred.

$\Rightarrow \quad$ Significantly, a greater proportion of MS students as compared to AF students have difficulty in understanding that the receipt of an order does not constitute a sale until the good has been shipped or the service fulfilled (Situation 6). It is the shipping date and not the date of the order that determines when sale has taken place. 
Table 3: Understanding of Revenue Recognition Situations

\begin{tabular}{|c|c|c|c|c|}
\hline \multirow[b]{2}{*}{ Situation Presented: } & \multicolumn{2}{|c|}{$\begin{array}{l}\text { \% of Students who } \\
\text { Correctly Recognized } \\
\text { Revenues }\end{array}$} & \multicolumn{2}{|c|}{$\begin{array}{c}\text { \% of Students who were } \\
\text { Very Confident or } \\
\text { Somewhat Confident of } \\
\text { Their Answer } \\
\end{array}$} \\
\hline & $\begin{array}{l}\text { Mktg/Sales } \\
\text { Majors } \\
(n=126)\end{array}$ & $\begin{array}{l}\text { Act/Fin } \\
\text { Majors } \\
(\mathbf{n}=\mathbf{1 0 0})\end{array}$ & $\begin{array}{l}\text { Mktg/Sales } \\
\text { Majors } \\
(n=126)\end{array}$ & $\begin{array}{l}\text { Act/Fin } \\
\text { Majors } \\
(\mathbf{n}=\mathbf{1 0 0})\end{array}$ \\
\hline $\begin{array}{l}\text { 1. Manufacturer ships goods to distributor with right to return. Can the } \\
\text { whole shipment be considered sales? }\end{array}$ & $47.6 \%$ & $50.0 \%$ & $47.6 \%$ & $56 \%$ \\
\hline $\begin{array}{l}\text { 2. Manufacturer ships more than what distributor ordered. Can } \\
\text { shipment be considered sales? }\end{array}$ & $85.7 \%$ & $88 \%$ & $69 \%$ & $70 \%$ \\
\hline $\begin{array}{l}\text { 3. Manufacturer ships goods to distributor at Christmas with right to } \\
\text { return unsold goods for refund. Can shipment be considered sales? }\end{array}$ & $57.1 \%$ & $69 \%$ & $53.2 \%$ & $69 \%$ \\
\hline $\begin{array}{l}\text { 4. Manufacturer ships goods to distributor at Christmas with right to } \\
\text { return unsold goods for refund. Manufacturer estimates a "reserve" } \\
\text { amount to offset goods returned in January. The reserve is rather } \\
\text { lower than the normally expected returns. Can shipment minus the } \\
\text { reserve be considered sales? }\end{array}$ & $42.1 \%$ & $47 \%$ & $30.2 \%$ & $45 \%$ \\
\hline $\begin{array}{l}\text { 5. Manufacturer ships goods to distributor with right to return unsold } \\
\text { goods. However, manufacturer pays distributor to delay return until } \\
\text { next year. Can whole shipment be considered sales this year? }\end{array}$ & $47.6 \%$ & $70.7 \% *$ & $50.8 \%$ & $56.6 \%$ \\
\hline $\begin{array}{l}\text { 6. Manufacturer received an order in December } 2005 \text { which was } \\
\text { shipped in January 2006. Can the order be considered sales for the } \\
\text { year 2005? }\end{array}$ & $25.6 \%$ & $61 \% *$ & $68 \%$ & $71 \%$ \\
\hline $\begin{array}{l}\text { 7. In 2006, Company A sold eight-years of licensing rights to } \\
\text { Company B for } \$ 8 \text { mil. Can } \$ 8 \text { mil be considered sales revenue for } \\
\text { year } 2006 \text { ? }\end{array}$ & $44.8 \%$ & $56.6 \%$ & $62.9 \%$ & $74.7 \%$ \\
\hline $\begin{array}{l}\text { 8. TV Channel A gave TV Channel B } \$ 10,000 \text { worth of ads on its } \\
\text { web-page. In exchange, TV Channel B agreed to give TV Channel } \\
\text { A } \$ 10,000 \text { worth of ads on its web-page. Can TV Channel A } \\
\text { consider } \$ 10,000 \text { ads from TV Channel B as sales revenue and its } \\
\text { ad on TV Channel B as ad expense? }\end{array}$ & $36.8 \%$ & $48 \%$ & $49.6 \%$ & $48 \%$ \\
\hline $\begin{array}{l}\text { 9. Medco has an agreement with several pharmacies and insurance } \\
\text { companies for the distribution of its prescription medicines. Under } \\
\text { that agreement, the pharmacy retains the patient's co-pay as its } \\
\text { compensation for filling the prescription. Meanwhile, the insurance } \\
\text { companies pay Medco directly for its pharmaceuticals minus co- } \\
\text { pay. Is it proper for Medco to claim the co-pays, which were paid } \\
\text { directly by the consumer to the pharmacies, as Medco's revenue } \\
\text { and then to claim the co-pays retained by pharmacies as its } \\
\text { expense? }\end{array}$ & $80.6 \%$ & $74 \%$ & $30.6 \%$ & $27 \%$ \\
\hline $\begin{array}{l}\text { 10. In } 2006 \text {, a copier manufacturer sold a machine for } \$ 50,000 \text { with } \\
\text { three year service agreement worth } \$ 12,000 \text {. Is it proper to consider } \\
\$ 62,000 \text { as sales for year } 2006 \text {. }\end{array}$ & $49.6 \%$ & $62 \%$ & $61.6 \%$ & $74 \%$ \\
\hline $\begin{array}{l}\text { 11. An electric Utility A bought and sold energy from Utility B when } \\
\text { the demand fluctuated. Is it proper to consider its sales of energy as } \\
\text { revenue and its purchase of energy as expenses? }\end{array}$ & $22.2 \%$ & $35.4 \% *$ & $40.8 \%$ & $47.5 \%$ \\
\hline $\begin{array}{l}\text { 12. In the third qtr of } 1999 \text { Priceline.com reported } \$ 152 \text { million as sales } \\
\text { which included the full amount that customers paid to Priceline for } \\
\text { airline tickets, hotel rooms, rental cars, etc. Priceline retains only } \\
\text { its broker's fee, } \$ 18 \text { million, with the rest of the payments going to } \\
\text { the airlines, hotels, and car rental companies. Is it proper for } \\
\text { Priceline.com to declare } \$ 152 \text { million as its sales revenue while } \\
\text { claiming the amount remitted to the airlines, hotels, and other } \\
\text { providers as its expense? }\end{array}$ & $41.3 \%$ & $44 \%$ & $44.4 \%$ & $42 \%$ \\
\hline $\begin{array}{l}\text { 13. An online College Admission's application processor collects an } \\
\text { application fee from students. It then keeps a portion of this fee as } \\
\text { its commission and remits the remainder to the colleges. Can the } \\
\text { application processor claim the entire amount of the application fee } \\
\text { as its revenue and the amount it remits to the colleges as its } \\
\text { expense? }\end{array}$ & $69.6 \%$ & $66 \%$ & $41.1 \%$ & $50 \%$ \\
\hline
\end{tabular}

* Difference in proportions significant at 0.05 level 
$\Rightarrow \quad$ In many instances companies sell products with service contracts (e.g. copying machines or individually tailored software) or license technology or other assets which generate a stream of cash flow over a period of time (Situation 7 and 10). Significantly fewer MS than the AF students realized that only a pro-rata portion of such service contracts and licensing fees can be counted as sales in the year a contract is signed. The revenue from the service contract or licensing agreement must be distributed over the life of the contract. Software contracts can be particularly tricky since they may extend for years and can involve the creation of software, maintenance, upgrades and other services. In this situation, the same overriding principle applies; the sale is claimed or recognized as the service is performed.

In the business world, companies exchange or buy and sell goods and services with each other, (Situations 8,9 and 11) sometimes via an intermediary and sometimes without any cash transaction. In such exchanges, only the net sale (the difference between the value given and the value received) can be reported as a sale. In two out of the three situations, a significant proportion of MS students could not correctly recognize whether sales have occurred. In some cases, subtle differences can determine whether a sale is recorded at its net or its gross amount. In Situation 12, the SEC ruled that Priceline.com can report its sales at gross, while in Situation 13, the SEC ruled that College Admissions must report its sales at net. MS students cannot be expected to be experts on such fine details, but should be aware that they ought to consult with accounting before crafting such agreements.

\section{CONCLUSION \& DISCUSSION}

An important objective of this article is to examine marketing/sales students' understanding of sales revenue and to stimulate a discussion about the teaching of sales revenue recognition issues in the marketing/sales curriculum. We identify extensive ignorance of revenue recognition issues among both accounting and marketing students. As expected, the problem is more acute among marketing/sales students than among finance/accounting students. The marketing students demonstrated total ignorance, as they scored no better than would be expected by random selection. Although accounting students scored significantly better than random selection and their marketing counter parts, their performance was disappointing. Questions number one through seven and number ten addressed basic issues that all accountants should know. The other questions addressed unusual situations.

Although revenue recognition may be perceived as an accounting issue, sales representatives are the front line of revenue management. They are with the customer, negotiating deals and bringing in business. The salesforce can potentially structure the details of a contract to allow its resulting revenues to be recognized in the earlier reporting period. In order to do so, they must have a basic understanding of revenue recognition rules and know when to consult accountants before consummating contracts. The accounting department, on the other hand, is typically restricted to applying the rules of revenue recognition to existing contracts and appropriately recording sales. It is, therefore, marketing that has the opportunity to impact when or whether a transaction can be claimed as a sale. It then falls to either the firm or to marketing faculty to educate the salesforce about revenue recognition rules and restrictions.

What role can educators play in preparing marketing and accounting students to address revenue recognition problems in the workplace? First, marketing students need to be sensitized to the fact that revenue recognition is a serious issue and the salesforce can play an important role in the timing of revenue recognition through their negotiations with customers. Second, accounting students should be taught a solid understanding of proper revenue recognition practices. Beyond the basics, accounting students should become skilled at researching the literature to determine the proper handling of unusual situations. The failure of accountants to properly recognize revenue could lead to the required reissuing of financial statements and create ethical, financial, and legal difficulties for the firm. In addition, the accountants could be jeopardizing their own careers and those of the firm's top executives under the Sarbanes-Oxley Act of 2002. Towards these ends, faculty should develop small cases or exercises that students can analyze and discuss in the class. These exercises should focus on developing students' skills in identifying sales recognition issues and make them cognizant that the details of contracts will impact their firm's reported sales. 


\section{AUTHOR INFORMATION}

Leon B. Hoshower, Ph. D., C.P.A., C.M.A, is a Professor of Accountancy at Ohio University. His research and teaching interests include performance measurement and cost control, $\mathrm{ABC}$ costing, and accounting education. He has over 50 published works, some of which have appeared in Management Accounting, Journal of Cost Management, Financial Executive, and Issues in Accounting Education. Professor Hoshower has conducted numerous seminars for the American Accounting Association and for the Institute of Management Accountants.

Dr. Ashok K. Gupta is a Professor of Marketing in the College of Business, Ohio University, Athens, Ohio. His research, teaching and consulting interests focus on management of innovation and new product development process. He has published in Journal of Marketing, California Management Review, Industrial Marketing Management, Journal of Business to Business Marketing and other journals. He is Editor-in-Chief of American Journal of Business.

\section{REFERENCES}

1. Anthony, Neal St. (2004), “The Squeeze is On: Revenue Practices Are Under Scrutiny,” Star Tribune (Minneapolis), February 5.

2. Butaney, Gul T., Ashok Gupta, and Leon Hoshower (2006), "What Counts as Sales Revenue in B-to-B Transactions?: The Regulatory and Marketing Management Issues," Journal of Business-to-Business Marketing, Vol. 13, No. 3, 2006, pp. 1-38.

3. $\quad$ Gillies, Andrew T. (2003), "Is That Revenue for Real?" Forbes, April 14.

4. Healy, P.M. and J.M. Wahlen (1999), "A Review of the Earnings Management Literature and its Implications for Standard Setting," Accounting Horizons, (October), 13, pp 365-383

5. Kahn, Jeremy (2000), "Presto Chango! Sales are Huge," Fortune, March 20.

6. Lehmann, Donald R. (2004), "Metrics for Making Marketing Matter," Journal of Marketing, Vol. 68 (October) pp 73-75.

7. Leuz, C., D. Nanda, and P. Wysecki (2003), "Earnings Management and Investor Protection: An International Comparison," Journal of Financial Economics, 69 (3), pp 505-527

8. Lichtenthal, J. David and Shay Eliaz (2003), "Internet Integration in Business Marketing Tactics," Industrial Marketing Management, 32 (January), 3-13.

9. Morris, Michael, Leyland Pitt, and Earl D. Honeycutt (2001), Business-to-Business Marketing: A Strategic Approach, Thousand Oaks, CA: Sage Publications

10. Nelson, Mark W., John A. Elliott, and Robin L. Tarpley (2003), "How are Earnings Managed? Examples from Auditors," Accounting Horizons Supplement, pp 17-35.

11. Palmrose, Z, V.J. Richardson, and S, Scholz, (2004), "Determinants of Market Reactions To Restatement announcements, Journal of Accounting and Economics, 37(1) : 1-32.

12. Powers, M. and L. Revsine (1989), "Lessors' Accounting and Residual Values: Comdisco, Barron's and GAAP," The Accounting Review (64) 2, 346-368

13. Pritchard, A. and S. Ferris (2001), "Stock Price Reactions to Securities Fraud Class Actions Under the Private Securities Litigation Reform Act," Working Paper, University of Michigan Law School.

14. RevenueRecognition.Com (2002), "Forging the Link Between Sales and Revenue Recognition" RevenueRecognition.com staff interview with Suzanne Rogers-MacCormack, V. P. of Finance \& Administration and CFO at Moldflow Corporation. http://www.revenuerecognition.com

15. Rust, Roland T., Tim Amber, Gregory S. Carpenter, V. Kumar and Rajendra K. Srivastava (2004), "Measuring Marketing Productivity: Current Knowledge and Future Directions," Journal of Marketing, Vol. 68 (October) pp. 76-89.

16. Stallworth, H. Lynn and Dean Digregorio (2004), “Improper Revenue Recognition”, Internal Auditor, June, (6) 3, 53-68

17. Turner, L. J.R. Dietrich, K. Anderson, and A. Bailey (2001), “Accounting Restatements,” Working Paper, Colorado State University.

18. U.S. Securities and Exchange Commission (2002), "SEC Charges Current Director of and Former Officers of First Virtual Communications, Inc. with Overstating Revenues and Earnings," Litigation Release No. 17869 / December 2. http://www.sec.gov/litigation/litreleases/lr17869.htm 
19. U.S. Securities and Exchange Commission (2003), "SEC Charges Peregrine Systems, Inc. With Financial Fraud And Agrees To Partial Settlement," Litigation Release No. 18205 / June 30. http://www.sec.gov/litigation/litreleases/lr18205.htm

20. U.S. Securities and Exchange Commission (2004), "SEC Sues Three Additional Former Senior Executives of Gemstar-TV Guide for Their Part in Financial Fraud," Washington, D.C., January 5.

\section{APPENDIX 1 REVENUE RECOGNITION SITUATIONS INCLUDED IN QUESTIONNAIRE}

SITUATION 1: FVC Inc. entered into an agreement with its largest distributor in which the distributor agreed to accept shipments of $\$ 3$ million of FVC products in exchange for FVC's agreement to grant the distributor product return rights on the shipment. At the time of shipment, can FVC claim the $\$ 3$ million as sales?

SITUATION 2: Healthy Foods Inc. shipped more cereal and cake mix than its distributors had actually ordered. Can Healthy Foods claim these excess shipments as sales at the time of shipment?

SITUATION 3: Action Games Inc. shipped a large number of games to department stores during the Christmas selling season with the understanding that the games that the department store did not sell could be returned for a refund. As of year end, Action Games does not know how many of these games will be returned. Can Action Games claim all of these Christmas season shipments as sales its in annual financial statements?

SITUATION 4: Interactive Video Games Inc. shipped a large number of games to department stores during the Christmas selling season with the understanding that the games which the department store did not sell could be returned for a refund. The company also "estimated" the amount of goods that would be returned and deducted this amount from their Christmas sales by setting up a reserve account. This reserve was used to offset the goods returned in January. However, the amount of this "reserve" was well below the amount of returns that normally occur. Can Interactive Video claim Christmas season shipments minus the reserve as sales in their annual financial statements?

SITUATION 5: Network Inc., a developer of software for computer security, shipped large amounts of software to its distributors. The distributors had the right to return the unsold software. However, Network Inc. paid the distributors to delay the return of the unsold software until next year. Can Network claim all of the shipment to distributors as sales this year?

SITUATION 6: Kraft Foods received a $\$ 2$ million order in December 2005. However, the order was shipped in January 2006. Can Kraft claim the $\$ 2$ million of sales in 2005 ?

SITUATION 7: In 2006, Shiny-Star, a Los Angeles-based media and technology company, sold XYZ eight-years of licensing rights for $\$ 8$ million. Can Shiny-Star claim $\$ 8$ million of revenue for 2006 ?

SITUATION 8: SuperMedia Network agreed to give WOUR $\$ 10,000$ worth of ads on its web page. In exchange, WOUR agreed to give SuperMedia $\$ 10,000$ worth of ads on its web page. Can SuperMedia count WOUR's $\$ 10,000$ worth of ads on its web page as sales revenue and the $\$ 10,000$ of its ads on WOUR's web page as ad expense?

SITUATION 9: Medco, a division of Merck, has an agreement with several pharmacies and insurance companies concerning the distribution of its pharmaceuticals. Under that agreement, the pharmacy retains the patient's copay as its compensation for filling the prescription. Meanwhile, the insurance companies pay Medco directly for its pharmaceuticals. Is it proper for Medco to claim the co-pays, which were paid directly by the consumer to the pharmacies, as Medco's revenue and then to claim the co-pays as its expense? 
SITUATION 10: In January 2007, TrueCopy Inc. sold a photocopy machine for $\$ 50,000$ with an accompanying three year service agreement for an additional $\$ 12,000$. Is it proper for TrueCopy to consider $\$ 62,000$ as sales revenue for year 2007 ?

SITUATION 11: To balance energy generation and consumption, Duke Energy, like other electric utilities, bought energy from and sold energy to other power companies. Is it proper for Duke to report all of its sales of energy as revenue and all of its purchases of energy as expenses?

SITUATION 12: In the third quarter of 1999, Priceline.com, an on-line travel service provider, reported its sales revenue as $\$ 152$ million. This amount included the full amount that customers paid to Priceline for airline tickets, hotel rooms, rental cars, etc. Priceline retains only its broker's fee, $\$ 18$ million that quarter, with the rest of the payments going to the airlines, hotels, and car rental companies. Is it proper for Priceline.com to declare $\$ 152$ as its sales revenue while claiming the amount remitted to the airlines, hotels, and other providers as its expense?

SITUATION 13: An online College Admission's application processor collects an application fee from students. It then keeps a portion of this fee as its commission and remits the remainder to the colleges. Can the application processor claim the entire amount of the application fee as its revenue and the amount it remits to the colleges as its expense? 